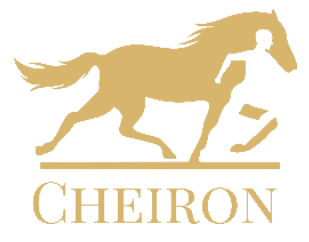

Cheiron: The International Journal of Equine and Equestrian History

Vol. 1, Issue 1/2021

(C) The Authors 2021

Available online at

http://trivent-publishing.eu/

\title{
Horse Burial in Lombard Italy: Crossing Cultural and Afterlife Boundaries in Social Representation
}

\author{
Irina Mattioli
}

\begin{abstract}
The custom of horse burial, of foreign extraction, was carried across the Italian borders by the Lombards during their migration in 568 AD. The buried horses are linked to a variety of human remains: not only warriors, but also young women, adult males without weapons, and men who did not possess the osteological markers of warriors. The focus is on one of the most interesting examples in Lombard Italy, the necropolis of Spilamberto, due to the unique association of horses with young ladies. This paper argues that the horses buried in the Italian Lombard necropolises (late sixth / seventh century), were cultural symbols borrowed from the warfare sphere, but primarily used, in death, as emblems of unique status, whether or not there was a factual involvement in warfarematters during life.
\end{abstract}

\section{Keywords}

Horse burial; Lombards; Horses; Animal History; Funerary Archaeology; Ritual custom.

DOI: 10.22618/TP.Cheiron.20211.1.233002

CHEIRON is published by Trivent Publishing

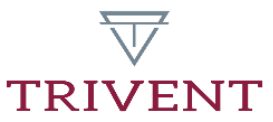

This is an Open Access article distributed in accordance with the Creative Commons Attribution Non Commercial (CCBY-NC-ND 4.0) license, which permits others to copy or share the article, provided original work is properly cited and that this is not done for commercial purposes. Users may not remix, transform, or build upon the material and may not distribute the modified material (bttp:/ / creativecommons.org/licenses/by-nc/4.0/) 


\title{
Horse Burial in Lombard Italy: Crossing Cultural and Afterlife Boundaries in Social Representation
}

\author{
Irina Mattioli ${ }^{1}$
}

\begin{abstract}
The custom of horse burial, of foreign extraction, was carried across the Italian borders by the Lombards during their migration in $568 \mathrm{AD}$. The buried horses are linked to a variety of human remains: not only warriors, but also young women, adult males without weapons, and men who did not possess the osteological markers of warriors. The focus is on one of the most interesting examples in Lombard Italy, the necropolis of Spilamberto, due to the unique association of horses with young ladies. This paper argues that the horses buried in the Italian Lombard necropolises (late sixth / seventh century), were cultural symbols borrowed from the warfare sphere, but primarily used, in death, as emblems of unique status, whether or not there was a factual involvement in warfarematters during life.
\end{abstract}

\section{Keywords}

Horse burial; Lombards; Horses; Animal History; Funerary Archaeology; Ritual custom.

\section{Introduction}

Increased finds of horse burials in Italy in recent years have led to heightened interest in the custom of such burials within the scholar community. ${ }^{2}$ This funerary practice of foreign extraction was carried across the Italian borders by the Lombards during their migration in $568 \mathrm{AD}$ and integrated in the Christian rituals without any seeming contradiction. ${ }^{3}$ Fourteen horse burials have been discovered, so far, in the Italian Lombard necropolises (dated between the seventies of the sixth and the half of the seventh century), and offer, in terms of

\footnotetext{
${ }^{1}$ Dipartimento di Studi Storici, Università degli Studi di Milano, Italy. School of History, University of St Andrews, Scotland - UK.

2 A. Chavarrìa Arnau and T. Lewit, "Uomini e animali nell'Italia longobarda," in Longobardi - un popolo che cambia la storia, ed. Gian Pietro Brogiolo, Federico Marazzi, Caterina Giostra (Milano: Skira, 2017), 162-165; C. Giostra, "Verso l'aldilà: i riti funerari e la cultura materiale," in Longobardi - un popolo che cambia la storia, ed. Gian Pietro Brogiolo, Federico Marazzi, Caterina Giostra (Milano: Skira, 2017), 6067. Also, two recent overviews: A. Fedele, "La deposizione del cavallo nei cimiteri longobardi: dati e prime osservazioni," in Archeologia dei Longobardi. Dati e metodi per nuovi percorsi di analisi, ed. Caterina Giostra (Mantova, 2017), 59-82; P. De Vingo, "Riding to Walhalla: the Role of Horses and Horsemen in Italian Funerary Rituals in the Early Middle Age," in Tra i Longobardi del Sud: Arechi II e il Ducato di Benevento, ed. Marcello Rotili (Padova: Il Poligrafo, 2017), 537-566.

${ }^{3}$ Christians of Arian faith.
} 
contents, a rather multifaceted scenario. ${ }^{4} \mathrm{~A}$ caveat when considering this practice is that we do not know if horse burial is actually rare in Italy, or if it is just underrepresented by the fortuity of the recoveries (a staple issue in archaeological research). The archaeological evidence links the horses to a variety of human burials: warriors, young women, adult males without weapons, and men who did not possess the distinctive osteological markers of warriors. Some of the burials capture the attention for their uniqueness and beauty, and we cannot avoid wondering what were the socio-cultural motives behind them. Due to the aforementioned typological variety of the findings, an all-inclusive answer is not possible at the moment. However, going through the archaeological evidence, considering the historical sources, and with an eye to the history of culture, it is possible to offer some hypothesis of interpretation.

In this article, I will focus on one of the most interesting examples of equestrian burial practice in Lombard Italy, the necropolis of Spilamberto, due to the unique association of horse burials with young women. ${ }^{5}$ This article argues that the horses buried in the Italian Lombard cemeteries, such as the necropolis of Spilamberto, were cultural symbols borrowed from the pre-Christian / warfare sphere. However, these symbols were primarily used, in death, as emblems of unique social status, whether or not there was a factual involvement of the buried horses or people interred with them in warfare during life.

\footnotetext{
${ }^{4}$ Spilamberto (Modena); Vicenne and Morrione at Campochiaro (Campobasso); Nocera Umbra (Perugia); San Mauro a Cividale (Udine); Povegliano (Verona); Collegno (Torino); Villa Lancia di Testona (Torino); Bovolone (Verona); Sacca di Goito (Mantova); Borgomasino (Torino); Mandello Vitta (Novara); Madonna del Cuore (Rieti); Fornovo San Giovanni (Bergamo).

${ }^{5}$ Part of my research about Lombard horse burial is discussed in a soon to be published article about four of the most interesting and well-documented sites in Italy: Campochiaro (with its two necropolises of Vicenne e Morrione), Spilamberto, Nocera Umbra e San Mauro di Cividale. In the two, close necropolises of Campochiaro, 19 harnessed horses have been buried in the same pit with 19 men: $\mathrm{V}$. Ceglia, "La necropoli di Campochiaro (Italia)," in Roma e i Barbari. La nascita di un nuovo mondo, ed. JeanJacques Aillagon (Milano: Skira, 2008), 469-475; V. Ceglia and I. Marchetta, "Nuovi dati dalla necropoli di Vicenne a Campochiaro," in La trasformazione del mondo romando e le grandi migrazioni. Nuovi popoli dall'Europa Settentrionale e Centro-orientale alle coste del Mediterraneo, ed. Carlo Ebanista and Marcello Rotili (Cimitile: Tavolario Edizioni, 2012), 217-238; A. Fedele, I. Marchetta and D. Colombo, "Ritualità e rappresentazione funeraria nelle tombe di Vicenne (Campochiaro, CB). Una sintesi," in Prima e dopo Alboino: sulle tracce dei Longobardi, ed. Carlo Ebanista and Marcello Rotili (Napoli: Tavolario Edizioni, 2019), 295-314. In the necropolis of Nocera Umbra, there was a horse buried with a dog, linked to a man's grave: A. Pasqui and R. Paribeni, "Necropoli barbarica di Nocera Umbra," Monumenti Antichi dei Lincei XXV (1918): 137-352; Cornelia Rupp, Das langobardische Gräberfeld von Nocera Umbra 1. Katalog und Tafeln (Firenze: All'insegna del Giglio, 2006). In the necropolis of San Mauro di Cividale the archaeologist unearthed the grave of a man buried with - and under - a horse: I. Ahumada Silva, "La necropoli di San Mauro in rapporto alle altre aree sepolcrali longobarde cividalesi," in Necropoli Longobarde in Italia: indirizzi della ricerca e nuovi dati, ed. Elisa Possenti (Trento: Museo Castello Buonconsiglio, 2014), 319-338; La collina di San Mauro a Cividale del Friuli. Dalla necropoli longobarda alla chiesetta bassomedievale, ed. Isabel Ahumada Silva (Firenze: All'Insegna del Giglio, 2010); P. Reggiani, "Intervento di recupero e restauro delle ossa del cavallo della tomba 43," in La collina di San Mauro a Cividale del Friuli. Dalla necropoli longobarda alla cbiesetta bassomedievale, ed. Isabel Ahumada Silva (Firenze: All'Insegna del Giglio, 2010), 247-249; A. Riedel, "Studio delle ossa del cavallo della tomba 43," in La collina di San Mauro a Cividale del Friuli. Dalla necropoli longobarda alla chiesetta bassomedievale, ed. Isabel Ahumada Silva (Firenze: All'Insegna del Giglio, 2010), 241-246.
} 


\section{Crossing cultural boundaries}

The ritual burial and sacrifice of horses in human cemeteries is a phenomenon of vast geographical and chronological range, that was probably introduced by various people spatiotemporally. ${ }^{6}$ The cultural expression has its deepest roots in the nomadic Eurasian world. The tradition is documented by Herodotus (IV, 72) for the Scythians (fourth-fifth century BC); by archaeological evidence for the Bronze and Iron Age; in the Middle East in China (Late Shang period, thirteenth-eleventh century BC), and in Central Asia with the burial of wagons as well. In the Eurasian area, the custom is widely attested during the Middle Ages in Southern Russia, Caucasus, the Danubian and Carpathian region. ${ }^{7}$

Certainly, the presence of equestrian burials in Italy is intriguing but the diversity of findings requires special attention. ${ }^{8}$ Frank Salvadori wrote that we can identify four different typologies of horse burial: the entire body; beheaded; composition of head, limbs, and tail; just the head. ${ }^{9}$ While the inhumation of the entire body and the one of the beheaded body might work as subcategories, ${ }^{10}$ the other two are not associated with the Lombard's customs in the Italian Peninsula, since they are underrepresented, from different dating periods or proven to be caused by later occurrences ${ }^{11}$. In Italy, the Lombard necropolises characterized by grave goods and ritual elements occurred between the seventies of the sixth and the early

6 A good overview in: P. J. Cross, "Horse Burial in First Millennium AD Britain: Issues of Interpretation," in European Journal of Archaeology 14 (Cambridge University Press, 2011), 190-209.

${ }^{7}$ B. Genito, "Sepolture con cavallo da Vicenne (CB): un rituale nomadico di origine centroasiatica," in Atti del I Congresso Nazionale di Archeologia Medievale, ed. Sauro Gelichi (Firenze: all'Insegna del Giglio, 2001), 1-4.

8 To investigate the Lombard society is also a difficulty on its own: due to the scarcity of written sources, Lombard studies rely mainly on (funerary) archaeology. I Longobardi e la storia - un percorso attraverso le fonti, ed. Francesco Lo Monaco and Francesco Mores (Roma: Viella, 2012); E. Possenti, "Necropoli longobarde in Italia: lo stato della ricerca," in Necropoli Longobarde in Italia: indirizzi della ricerca e nuovi dati, ed. Elisa Possenti (Trento: Museo Castello Buonconsiglio, 2014), 35-54.

${ }^{9}$ F. Salvadori, "Indicatori archeozoologici nell'età della transizione," in Atti del V Congresso Nazionale di Archeologia Medievale, ed. Giuliano Volpe and Pasquale Favia (Firenze: All'Insegna del Giglio, 2009), 42.

10 According to Farello and Riedel, the custom of burying beheaded horses in human cemeteries is a minor/secondary one, visible mostly during the Age of Migration. P. Farello, "I cavalli longobardi di Spilamberto," in Il Tesoro di Spilamberto - Signori Longobardi alla frontiera, ed. Andrea Breda (Spilamberto: Comune di Spilamberto, 2010), 91-97; A. Riedel, "Le inumazioni animali della necropoli longobarda di Povegliano (VR)," Annali dei Musei Civici di Rovereto 11 (1996): 53-98.

${ }^{11}$ In Italy, the only example of the composition of a horse's head, limbs and tail is in Arzignano, a necropolis dating back to the mid-fifth century; this kind of evidence has been interpreted more as a food offer and, outside the Peninsula, is attested only for the fourth and fifth century, between NorthEast Europe and North-central Asia in Hun contexts; E. Possenti, "Una tomba di cavaliere della metà del V secolo da Arzignano (Vicenza)," Archeologia Medievale XXXVIII (2011): 431-475. As for the burial of autonomous heads, though the discovery of isolated skulls is not rare in Southern Germany, the only example offered by Salvadori for Italy is the one of Sacca di Goito, where the lack of the body has actually been linked to later damages not pertinent to the original burial ceremony. Another example of the burial of autonomous heads might be in Povegliano where, beyond a grave containing a horse and two dogs, two isolated heads have been found. However, they have not been studied yet; E. M. Menotti, P. M. De Marchi, L. Miazzo, "La necropoli longobarda a Sacca di Goito," in La necropoli longobarda a Sacca di Goito. I primi materiali restaurati. Catalogo della mostra, ed. Elena M. Menotti, Paola M. De Marchi, Lucia Miazzo (Mantova: Publi-Paolini, 1994), 33-40; A. Riedel, "Le inumazioni animali della necropoli longobarda di Povegliano (VR)," Annali dei Musei Civici di Rovereto 11 (1996), 58; F. Salvadori, "Indicatori archeozoologici nell'età della transizione," Atti del V Congresso Nazionale di Archeologia Medievale, ed. Giuliano Volpe and Pasquale Favia (Firenze: All'Insegna del Giglio, 2009), 40-44. 
seventh century. The horse burials, when dateable, have been mostly ascribed to the cemeteries' first phase of usage. ${ }^{12}$ Overall, while the Lombards quickly adopted or integrated ${ }^{13}$ many local habits and elements ${ }^{14}$ their culture remained characterized by pre-migratory features for several generations. For instance, according to the Edict of Rothari (the Lombardic law code, written in $643 \mathrm{AD}$, about 70 years after their arrival in Italy), being able to confirm and recite the parentilla - i.e., your own parentage for seven generations - was the only way to claim your inheritance. ${ }^{15}$ Thus, we can presume that the Lombard pre-migratory heritage (probably in a poetic form ${ }^{16}$ ), was still very lively in the collective memory. In fact, tracing one's bloodline back that far meant returning to very moment of the Lombards' migration: a stage of crucial ethnogenesis of the people's history, that the Origo Gentis Langobardorum ${ }^{17}$ and the Historia Langobardorum ${ }^{18}$ hand down deeply mixed with legend. ${ }^{19}$ We can assume that these

\footnotetext{
12 Between the late sixth to the mid-seventh century AD. Except for the necropolis of Campochiaro, which has a wider timespan of use and where some scholars tend to attribute the horse burials to a later time, although they rely on theories mostly based on the uncertain testimonies of Paul the Deacon; V. Ceglia, "La necropoli di Campochiaro (Italia)," in Roma e i Barbari. La nascita di un nuovo mondo, ed. JeanJacques Aillagon (Milano: Skira, 2008), 469-475; V. Ceglia and I. Marchetta, "Nuovi dati dalla necropoli di Vicenne a Campochiaro," in La trasformazione del mondo romando e le grandi migrazioni. Nuovi popoli dall'Europa Settentrionale e Centro-orientale alle coste del Mediterraneo, ed. Carlo Ebanista and Marcello Rotili (Cimitile: Tavolario Edizioni, 2012), 217-238; A. Fedele, "Horse burials among the Lombards and Avars. Some differences and similarities between the Germanic and Nomadic rituals," in The Materiality of the Horse, ed. Miriam A. Bibby and Brian G. Scott, (Budapest: Trivent, 2020), 239-260. However, doubts about the link between Campochiaro and the facts narrated by Paul the Deacon have been express by Cristina La Rocca and Chiara Provesi; C. La Rocca, "Reperti longobardi della necropoli di Povegliano, conservati nel Museo di Castelvecchio di Verona," in I Longobardi e la guerra: da Alboino alla battaglia sulla Livenza - sec. VI-VIII (Roma: Viella, 2004), 144-158; C. Provesi, "Uomini e cavalli in Italia Meridionale: da Cassiodoro ad Alzecone," in Ipsam Nolam Barbari Vastaverunt. L'Italia e il Mediterraneo Occidentale tra il V secolo e la metà del, ed. Carlo Ebanista - Marcello Rotili (Cimitile: Tavolario Edizioni, 2010), 97-112.

${ }^{13}$ Claudio Azzara - Giuseppe Sergi, Invasione o migrazione? I longobardi in Italia (Torino: Aragno, 2006); S. Gasparri, "I Germani immaginari e la realtà del regno. Cinquant'anni di studi sui Longobardi," in I Longobardi dei ducati di Spoleto e Benevento. Atti del XVI congresso internazionale di studi sull'alto medioevo I (Spoleto: Fondazione CISAM, 2003), 3-28; Il Regno dei Longobardi in Italia - Archeologia, società e istituzioni, ed. Stefano Gasparri (Spoleto: Fondazione CISAM, 2004); Walter Pohl, Le origini etniche dell'Europa Barbari e Romani tra antichità e medioevo (Roma: Viella, 2000).

14 The local people's Latin language and its written culture, for instance.

15 "Leges Langobardorum," in Le leggi dei longobardi - storia, memoria e diritto di un popolo germanico, ed. Claudio Azzara and Stefano Gasparri (Milano: Viella, 2005), 46-47.

${ }^{16}$ In the genealogy of king Rothari, the alliterative rhythm of the names is noticeable and was probably a way to help the memory; S. Gasparri, "La memoria storica dei Longobardi", in Le leggi dei longobardi storia, memoria e diritto di un popolo germanico, ed. Claudio Azzara and Stefano Gasparri (Milano: Viella, 2005), xxiv.

17 The Origo Gentis Langobardorum ("Origin of the tribe of the Lombards") is a short seventh century AD text narrating the founding myth of the Lombards. The text has been preserved and passed down in three manuscripts containing the Lombard law, serving as 'prologue' in the Edict of Rothari.

18 Historia Langobardorum ("The History of the Lombards"), is a six-books work by Paul the Deacon, written in the late 8th century AD.

19 Stefano Gasparri, La cultura tradizionale dei Longobardi - struttura tribale e resistenze pagane (Spoleto: Fondazione CISAM, 1983), 82-83; Walter Pohl, Le origini etniche dell'Europa - Barbari e Romani tra antichità e medioevo (Roma: Viella, 2000).
} 
pre-migratory cultural survivals ${ }^{20}$ - of which the horse burial is a clear example - belonged to a way of thinking still deeply connected to the Lombards' ancient tribal ethos and were powerful identity elements for the collective consciousness.

In the attempt to measure the importance that horses had among Lombards beyond their symbolic meaning, it is essential to understand the role they had in their society. We should ask ourselves what it meant to sacrifice a horse, for ritual purposes, in a community of the sixth-seventh century. ${ }^{21}$ According to the archaeozoological study of the examined cases, some of the immolated horses were old and infirmed, and others were young and healthy. To sacrifice a young and healthy horse, is to sacrifice a resource. After all, among the Lombards of those centuries, just as in other times, the property of these animals was probably a sign of wealth, and it is possible to find a trace of this value in their legislation. The Lombards' legislation covers a vast list of legal circumstances related to horses and their importance visibly stands out relative to the other animals mentioned, such as dogs, deer, pigs, oxen, and other types of livestock. In the Lex Langobardorum there are many paragraphs regarding the care of horses, their protection, and the defense of their owner's rights. There were penalties not only for proper offences against the horses 22 but also for actions entailing a lack of respect or integrity to these animals, as in Rothari 338: "Of the tail of a horse. If somebody cuts the tail of someone else's horse, that is just the hair, he must pay six solidi." 23 The actual theft of a horse is described in Rothari 342, and, in Rothari 340, riding someone else's horse outside the village without the owner's authorization is made punishable by a sanction in actogild (i.e., the reimbursement of nine times the price of the horse), a penalty that may seem very harsh for such a seemingly minor offence. ${ }^{24}$ Another peculiar law later issued by King Liutprand describes a case in which a horse or an ox are given as pledge to a creditor: if the owner is not able to retrieve them within a certain number of days, they are to be considered lost. However, it is curious and meaningful that if the animal, while in custody: "pulsatus fuerit, quod iniquo

${ }^{20}$ Like the mid-seventh century ritual described in the later Life of Saint Barbatus, bishop of Benevento (early ninth century AD): in some established days, an unidentified animal's skin was to be hanged to a tree not far from the city's wall; after that, the participants to the game had to challenge each other in a horse race, reach the animal's skin, tear it in pieces with their spears and eat it; Vita Barbati episcopi Beneventani, in Monumenta Germaniae Historica. Scriptores rerum Langobardicarum et Italicarum saec. VI-IX, ed. Georg Waitz, (Hannover, 1878), 555-563.

${ }^{21}$ Carte di famiglia. Strategie, rappresentarione e memoria del gruppo familiare di Totone di Campione (721-877), ed. Stefano Gasparri and Cristina La Rocca (Roma: Viella 2005); Guy Halsall, Settlement and social organization (Cambridge: Cambridge University Press, 1995); Chris Wickham, Framing the Early Middle Ages: Europe and the Mediterranean, 400-800 (Oxford: Oxford University Press, 2005).

22 Paragraphs: 337, 339, 341; Le leggi dei longobardi - storia, memoria e diritto di un popolo germanico, ed. Claudio Azzara - Stefano Gasparri (Milano: Viella, 2005), 96-97.

23 "De coda caballi. Si quis caballum alienum coda cappellaverit, ide est setas tantum, conponat solidos sex", Rothari 338, Le leggi dei longobardi - storia, memoria e diritto di un popolo germanico, ed. Claudio Azzara and Stefano Gasparri (Milano: Viella, 2005), 96. The tail was probably cut in order to use it for the helmet's crest, as shown on the Lamina of Agilulfo. Anyway, given the great symbolic importance of hair for the Lombards, this act probably damaged the value of the animal on many levels: Paul the Deacon describes the shaving of Rothari duke of Benevento by King Aripert II as a way of striping his enemy of further social dignity and political aims. Paulus Diaconus, Historia Langobardorum, VI, 20, cit., 322-325.

24 "Si quis cavallum alienum ascenderit et infra vicinia tantum cavallicaverit, ide est prope ipsum vicum, conponat solidos duos; nam si inantea eum caballicare presumpserit et dominum non rogaverit, in actogild reddat", Rothari 340, Le leggi dei longobardi - storia, memoria e diritto di un popolo germanico, ed. Claudio Azzara and Stefano Gasparri (Milano: Viella, 2005), 96-97. 
animo" 25 - i.e., if it was mistreated - the law commands to make amends praying on the Gospels.

Horses were a vital part of life and, for a while, death, in Lombard society. It must have been hard to decide to give up a horse for ritual purposes. As a matter of fact, the osteological studies performed on some of the Italian remains seem to confirm that the sacrificed animal was not always a strong, young war-horse associated with an adult man. After all, we must remember that graves do not necessarily reflect the living social roles of the deceased but can be seen, rather, as "deforming mirrors," 26 parts of a symbolic play performed in front of the gathered community. For instance, the horse of Povegliano Veronese, according to Alfredo Riedel, was a gelded young male with clear signs of spinal column deformation (vertebral fusion and spondylosis). These types of degeneration are normally the result of a prolonged working use, and it has therefore been suggested that this specific horse was chosen for the sacrifice because of its weakened conditions ${ }^{27}$. Moreover, the osteological analysis conducted on the horses of Vicenne (Campochiaro) indicates that the animals were old at the time of death, and were affected by the pathological consequences typically associated with heavy works and prolonged efforts related to domestic and agricultural use. ${ }^{28}$ In this case, men and horses were buried together in the same pit, both with grave-goods, and the horses wore harness. Apparently, in this necropolis they were used as "military" symbols, but they were not (at least, not always or exclusively) the war-mounts of the deceased. ${ }^{29}$ Furthermore, in the necropolis of Spilamberto, the buried animals were young, but their genetic features and pathological degeneration indicated that they were likely not involved in military use. Their association with three young women seems to confirm such an instance.

\section{The Fair Ladies of Spilamberto}

The cemetery of Spilamberto (Cava di Ponte del Rio), was discovered in 2003 and excavated between 2003 and 2009. It consisted of 28 graves containing a total of 29 individuals, ${ }^{30}$ suggesting it was used only for one or two generations (Figure 1). The cemetery dates between the later sixth and the start of the seventh century. ${ }^{31}$ No link between the burial site and a specific residential settlement has been proven, or confirmation of the habitation of the pre-

25 "If [the animal] is abused with cruelty"; Le leggi dei longobardi - storia, memoria e diritto di un popolo germanico, ed. Claudio Azzara and Stefano Gasparri (Milano: Viella, 2005), 202-203.

${ }^{26}$ S. Brather, "Vestito, tomba ed identità fra Tardo Antico ed Alto Medioevo," in Archeologia e società tra Tardo Antico e Alto Medioevo, ed. Gian Pietro Brogiolo and Alexandra Chavarrìa Arnau (Mantova: Società Archeologica Mantova, 2007), 304.

27 A. Riedel, "Le inumazioni animali della necropoli longobarda di Povegliano (VR)," Annali dei Musei Civici di Rovereto 11 (1996), 53.

${ }^{28}$ C. Provesi, I cavalieri e le loro donne. Uno studio dei corredi funerari di VI - VII secolo secondo una prospettiva di Gender (Venice, 2011), 4.

${ }^{29}$ Nevertheless, the possibility that the two uses were not mutually exclusive must be considered as well: depending on the historical moment, a horse could have been used before in war and later, maybe because of its old age, in a domestic-agricultural context.

${ }^{30}$ E. Fiorin, "Alcune valutazioni preliminari sui defunti longobardi di Spilamberto," in Il Tesoro di Spilamberto - Signori Longobardi alla frontiera, ed. Andrea Breda (Spilamberto: Comune di Spilamberto, 2010), 87.

31 P. De Vingo, "Spilamberto, Archeologia di una necropoli longobarda," in Il Tesoro di Spilamberto Signori Longobardi alla frontiera, ed. Andrea Breda (Spilamberto: Comune di Spilamberto, 2010), 29-67; M. Marinato - A. Chavarria Arnau, "Approcci multidisciplinari per lo studio dei contesti cimiteriali longobardi: il sito di Spilamberto Cava Ponte del Rio (MO)," in VIII Congresso nazionale di Archeologia Medievale (Firenze: All'Insegna del Giglio, 2018), 33-37. 
existing late antique settlements in the area. ${ }^{32}$ The graves are, for the most part, simple terrain tombs (some of them edged with cobblestones), with an east-west orientation. One of the main characteristics of the site is the higher number of female tombs compared to the male tombs; moreover, among the males, just three of them were buried with weapons (swords, spears and/or shields). ${ }^{33}$ According to the excavation's record, there are eight male graves, fourteen female ones and seven unidentified. Due to the poor preservation state of the skeletal remains, it is however important to highlight that the gender designation of the individuals buried in Spilamberto was mainly inferred from the tomb furnishings. ${ }^{34}$ In other words, these burials are primarily sexed from grave goods rather than from biological measurements. Whether gender represented in grave goods always reflects biological sex is uncertain and something to keep in mind while we wait for further biological data. ${ }^{35}$ Various theories have been previously proposed to explain the "absence" of warriors in Spilamberto. For instance, warriors were more likely to die far from home in a battle resulting in lack of male burials, or there was a conscious choice of the community to invest chiefly on the women's ritual burial as a way to secure the hereditary transmission of their status to their families. ${ }^{36}$ The female grave goods appear very rich and, as in many other Lombard cemeteries, show a clear receptivity of both Roman and Byzantine tastes and styles. Some of the high-rank graves contained, amongst other items, cast bronze jars, a heavy bronze lamp, a silver spoon with an auspicious Roman inscription, a disc fibula made with an older cameo

32 D. Labate, "L'insediamento antico nell'area della necropoli longobarda di Spilamberto," in Il Tesoro di Spilamberto - Signori Longobardi alla frontiera, ed. Andrea Breda (Spilamberto: Comune di Spilamberto, 2010), 25.

${ }_{33}$ Il Tesoro di Spilamberto - Signori Longobardi alla frontiera, ed. Andrea Breda (Spilamberto: Comune di Spilamberto, 2010), 7-11.

${ }^{34}$ E. Fiorin, "Alcune valutazioni preliminari sui defunti longobardi di Spilamberto", in Il Tesoro di Spilamberto - Signori Longobardi alla frontiera, ed. Andrea Breda (Spilamberto: Comune di Spilamberto, 2010), 87-89. On gender attribution and grave goods: I. Barbiera, "Il mistero delle donne scomparse. Sex-ratio e società nel medioevo italiano," Archeologia Medievale XXXV (2008), 491-501; I. Barbiera, "Le dame barbare e i loro invisibili mariti: le trasformazioni dell'identità di genere nel V secolo," in Le trasformazioni del $V$ secolo: l'Italia, i barbari e l'Occidente romano, Atti del seminario di Poggibonsi (18 - 20 ottobre 2007), ed. Paolo Delogu and Stefano Gasparri (Turnhout: Brepols, 2010), 123-155; A. Gasparini, (Re)Viewing the Evidence: Using traditional and modern techniques to question gender and migration in the 7 th century necropoleis of Campocbiaro (Molise, Italy), unpublished dissertation, Supervisor: Prof. M. G. Belcastro University of Bologna (Bologna, 2019), 9-10; C. La Rocca, "Storia di genere e archeologia dell'alto medioevo: note sul dibattito europeo," in Archeologia e società tra Tardo Antico e Alto Medioevo, ed. Gian Pietro Brogiolo and Alexandria Chavarría Arnau (Mantova: SAP, 2007), 265 - 277; C. La Rocca, "Foreign dangers: activities, responsibilities and the problem of women abroad," in Early medieval Europe, vol. 23 (Wiley, 2015), 410-435.

${ }^{35}$ Cases of wrong sex attribution due to over-reliance in gender's cultural features of the grave-goods happened in the past. For instance, the well-known misinterpretation of the Viking warrior woman buried at Birka (Sweden), long assumed to be male, but biologically female; N. Price, C. HedenstiernaJonson, et al., "Viking warrior women? Reassessing Birka chamber grave Bj.581," Antiquity, 93, (Cambridge University Press, 2019), 181-198.

${ }^{36}$ C. Provesi, I cavalieri e le loro donne. Uno studio dei corredi funerari di VI - VII secolo secondo una prospettiva di Gender (Venice, 2011), 10-11. Also: Tesori: forme di accumulazione della ricchezza nell' alto Medioevo, secoli V-XI, ed. Sauro Gelichi - Cristina La Rocca (Roma: Viella, 2004). 
edged with water pearls and glass paste, ${ }^{37}$ a glass drinking horn, a chain mail mitten, and a sella plicatilis (an iron folding chair) with damascening brass motifs. ${ }^{38}$

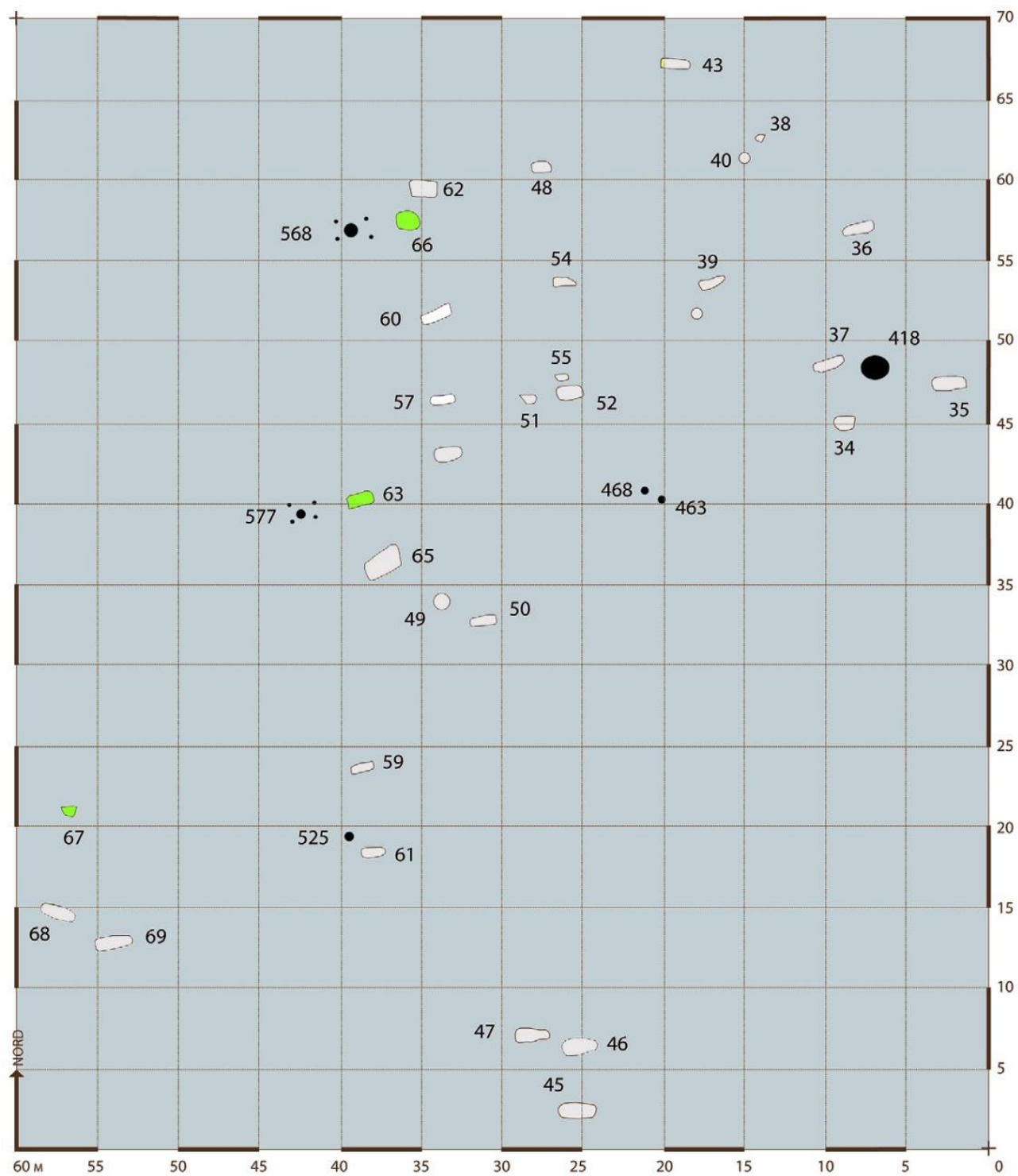

Fig. 1. Spilamberto, distribution map of horse burials (green) and ritual pits (black).

${ }^{37}$ N. Giordani, "Il pendente-fibula della tomba femminile 62," in Il Tesoro di Spilamberto - Signori Longobardi alla frontiera, ed. Andrea Breda (Spilamberto: Comune di Spilamberto, 2010), 77-85.

${ }^{38}$ For an overview of the grave goods in the necropolis of Spilamberto: P. De Vingo, P. Baronio and G. Maddaleno, "Spilamberto (MO), Necropoli Longobarda," in Medioevo Svelato - Storie dell'EmiliaRomagna attraverso l'archeologia, ed. Sauro Gelichi and Cinzia Cavallari - Massimo Medica (Bologna: Ante Quem, 2018), 203-207. 
Three decapitated horses were also discovered at Spilamberto. ${ }^{39}$ Based on the archaeological record and the stratigraphy the three animals, though buried individually, were linked to three wealthy female graves - all of sub-adults, one of which was a girl of 12 years old ${ }^{40}$ - instead of the expected warriors' graves. ${ }^{41} \mathrm{It}$ is worth of noting that, even though these three graves were wealthy and displayed extremely rich grave goods as mentioned - consistent with warrior/elite horse burials - they did not include any type of weapons. This means that they were not associated with any other "military elements" apart from horses. The horses were all young males and, in contrast to other known cases, ${ }^{42}$ there were no osteological signs indicating the manner in which they were killed and decapitated. The practice of burying decapitated horses in human cemeteries, though relatively widespread among the Italian cases, is however a secondary one, mostly occurring during the Age of Migration. ${ }^{43}$

All three horses were buried in terrain pits (t.63, t.66, t.67), without harnesses, trappings, or any kind of grave goods (Figures 2 and 3). The post-cranial articulated skeletons were all laying on their left side, with the legs slightly bent and the neck in an elevated position and turned "backwards" to the female human burials with which they are associated (t.65, t.62, t.68). In addition, near two of the horses' burials and in clear association with them (and probably near the third as well, though poorly preserved, and harder to detect), there were ritual pits. The round terrain ritual pits were surrounded by four pole holes which suggests a pre-existing enclosure or wooden structure. The pit 568 , the one that the archaeologists linked to the equine grave t.66, contained: "fragments of the unburnt horse's mandible, with traces of ash, and was broken in antiquo in some points, plus two of the horse's molars." ${ }^{4}$ From the archaeological evidence, we can infer the existence of a complex funerary practice that included the previously removed horse's head, in a ritual probably performed in front of the gathered community and complementary to the burial of the body. Admittedly, in many times and places across Northern European cultures, the horse head, apart from being an apotropaic element, is associated with fertility, augury, and ancestors' rituals. ${ }^{45}$

39 P. Farello, "I cavalli longobardi di Spilamberto," in Il Tesoro di Spilamberto - Signori Longobardi alla frontiera, ed. Andrea Breda (Spilamberto: Comune di Spilamberto, 2010), 91-97.

40 P. De Vingo, "Corredo funerario ed elementi del costume femminile della tomba 62 della necropoli longobarda di Spilamberto (MO), Cava di Ponte del Rio," in Medioevo Svelato - Storie dell'Emilia-Romagna attraverso l'archeologia, ed. Sauro Gelichi, Cinzia Cavallari and Massimo Medica (Bologna: Ante Quem, 2018), 230-234.

${ }^{41}$ To this day, there are no other cases of Lombard horse burial with women in the Italian Peninsula.

${ }^{42}$ Like, for instance, in the case of the beheaded horse found in the necropolis of Collegno (TO), where the osteological signs of the beheading are clearly visible; E. Bedini, "Il cavallo," in Presenze longobarde. Collegno nell'alto medioevo, ed. Luisella Pejrani Baricco (Torino: Soprintendenza per i beni archeologici del Piemonte, 2004), 137-240; E. Bedini - E. Petiti, "Fedeli oltre la morte. Sepolture di animali in necropoli longobarde. Gli esempi del Piemonte," in Atti del VI Convegno Narionale di Archeozoologia, ed. Jacopo De Grossi Mazzorin, Daniela Saccà and Carlo Tozzi (Lucca: Ass. Italiana Archeozoologia, 2012), 335; E. Bedini and E. Petiti, "Sepolture animali in necropoli longobarde: gli esempi del Piemonte," in Necropoli Longobarde in Italia: indirizzi della ricerca e nuovi dati, ed. Elisa Possenti (Trento: Museo Castello Buonconsiglio, 2014), 550-556.

43 A. Riedel, "Le inumazioni animali della necropoli longobarda di Povegliano (VR)," in Annali dei Musei Civici di Rovereto 11 (1996): 58.

44 P. Farello, "I cavalli longobardi di Spilamberto," in Il Tesoro di Spilamberto - Signori Longobardi alla frontiera, ed. Andrea Breda (Spilamberto: Comune di Spilamberto, 2010), 91-92, cit., 92.

45 P. J. Cross, "Horse Burial in First Millennium AD Britain: Issues of Interpretation," European Journal of Archaeology 14 (Cambridge University Press, 2011), 198-199; P. Jones and N. Pennick, A History of Pagan Europe (London: Routledge, 1995), 140; Ralph Merrifield, Archaeology of Ritual and Magic (London: B.T. Batsford, 1987), 47. 
According to the archaeozoology studies of Patrizia Farello, the horses of Spilamberto show genetic familiarity with Asiatic and Mongolic equine breeds, and with the Scandinavian breed known as Fjord. Therefore, these buried horses were probably not "war horses"; they were multipurpose animals, good for domestic use in transportation, under saddle and in draught, and for plowing and general farm work. Consistently, the animal from t.66 shows clear signs of deforming arthritis on the spinous processes of the thoracic vertebrae, which indicates that this horse was likely used as a pack animal for an extended time period, probably with a packsaddle. We do not know if these three horses belonged to the ladies with whom they were associated, or if they were just "expendable" animals sacrificed to serve as symbols. However, given their young age and phylogenetic features, they might have been the young female humans' horses. ${ }^{46}$ After all, if sacrificing a horse meant giving up on a great source of wealth and an important resource - especially in the case of a young animal - then it is reasonable to assume that such a choice was a conscious and a rather meaningful one.

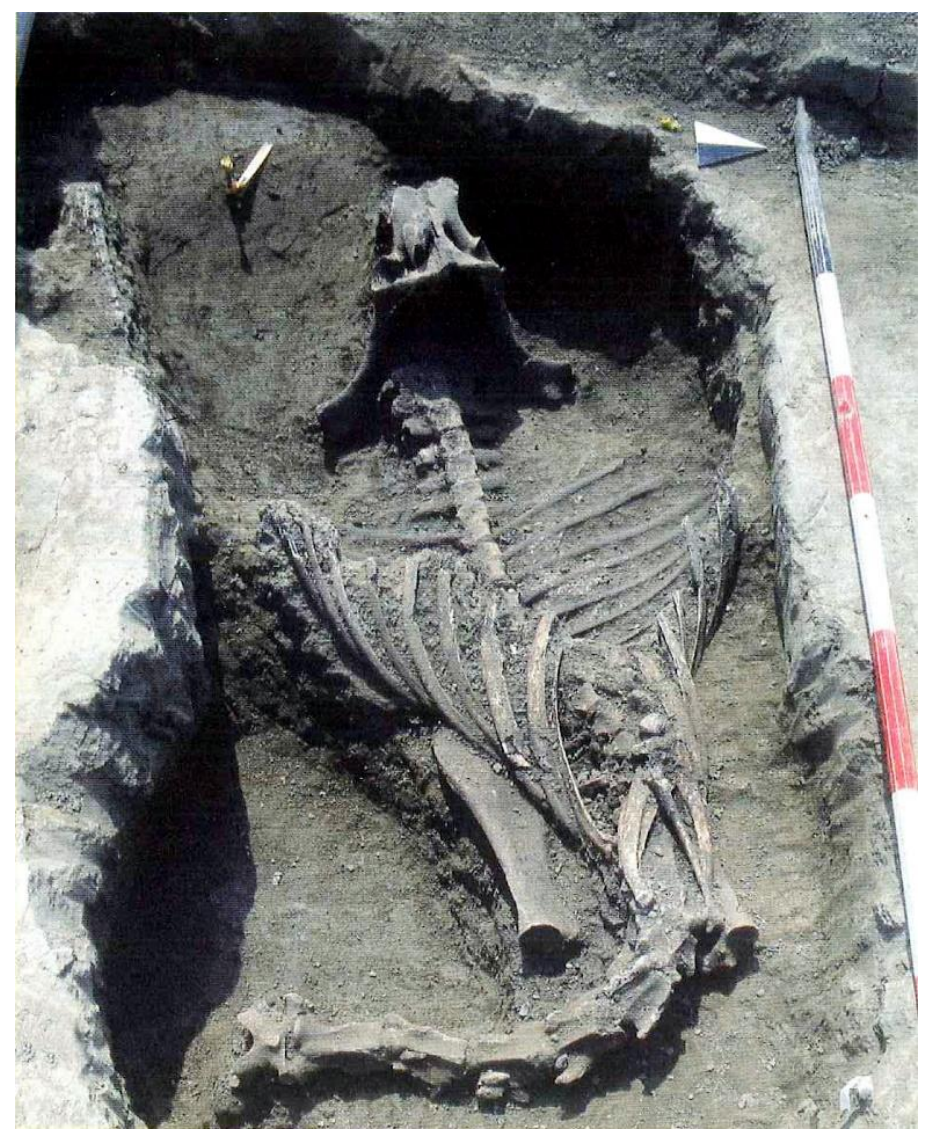

Fig. 2. Horse burial T. 63, from Il Tesoro di Spilamberto - Signori Longobardi alla frontiera, ed. Andrea Breda (Spilamberto: Comune di Spilamberto, 2010), 90.

\footnotetext{
${ }^{46}$ The three horses, according to the suture fusion of the postcranial bones, were estimated to have been 7 years old (t. 66), 2-3 years old (t. 63), and 2-3 years old (t. 67), at the time of death; P. Farello, "I cavalli longobardi di Spilamberto," in Il Tesoro di Spilamberto - Signori Longobardi alla frontiera, ed. Andrea Breda (Spilamberto: Comune di Spilamberto, 2010), 91-93.
} 


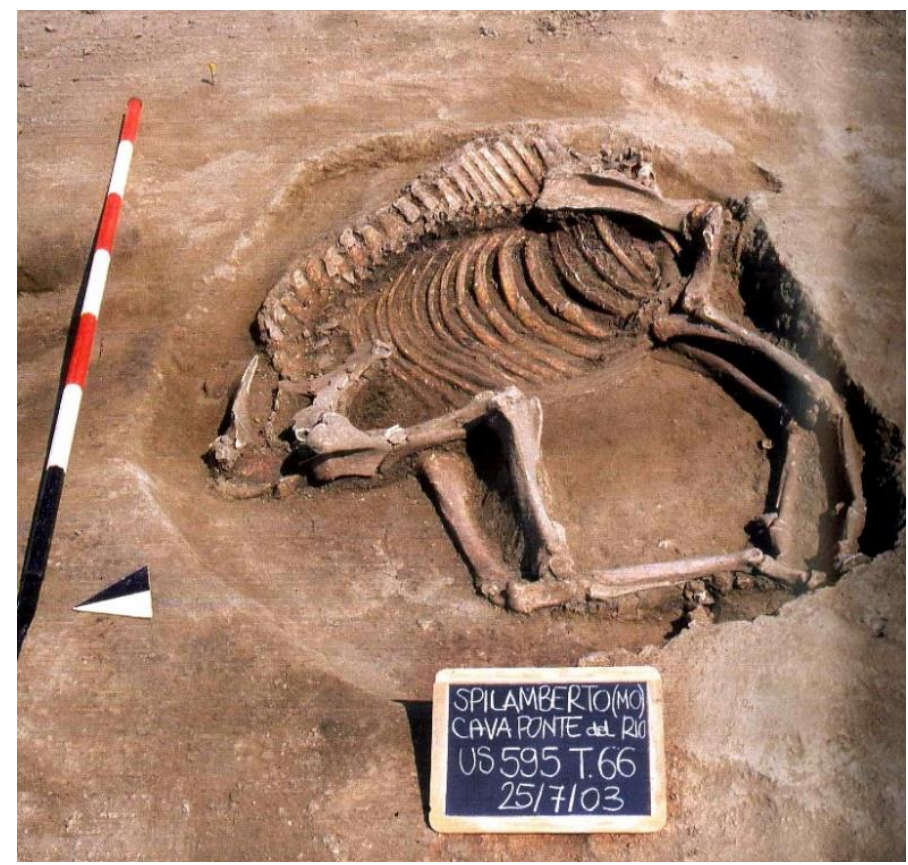

Fig. 3. Horse burial T. 66, from Il Tesoro di Spilamberto - Signori Longobardi alla frontiera, ed. Andrea Breda (Spilamberto: Comune di Spilamberto, 2010), 93.

\section{Crossing afterlife boundaries}

In the history of culture, the horse is often characterized by a sacred, numinous connotation. Its connection with the Afterlife seems rooted in the collective consciousness already in the old Indo-European and Uraltaic populations. ${ }^{47} \mathrm{~A}$ horse's skull is an apotropaic symbol in various cultures, often regarded as capable of guarding and protecting houses, ${ }^{48}$ and it is also, in many times and places, the ultimate sacrificial victim..$^{49}$ In the cultures of Northern Europe and Central-Asia - which underlie that of the Lombard in the sixth-seventh centuries (and beyond) - the horse possesses an otherworldly connotation. A creature that, amongst others, holds special ties with several essential and interconnected dimensions: hunting, war, spirituality, and death. Moreover, the horse's relationship with its owner was seen as strong and sacred, something that the medieval Latin culture was later to adopt and enhance. It is not surprising then, that in these cultures the horse was the elected companion for elite individuals, chosen for the longest of all travels into the Afterlife.

\footnotetext{
${ }^{47}$ R. Bleichsteiner, "Roßweihe und Pferderennen im Totenkult der kaukasischen Völker," in Wiener Beiträge zur Kulturgeschichte und Linguistik. IV (1936): 413-495; Gianna Chiesa Isnardi, I miti nordici (Milano: Longanesi, 1991); Mircea Eliade, Lo sciamanismo e le tecniche dell'estasi (Roma: Mediterranee, 1985).

${ }^{48}$ Franco Cardini, Alle radici della cavalleria medievale (Città di Castello: La Nuova Italia, 1981), 43; Ralph Merrifield, Archaeology of Ritual and Magic (London: B.T. Batsford, 1987), 123-129.

49 Adam of Bremen writes about a big festival in Uppsala, taking place every nine years, where the meat of sacrificed horses was considered privileged food; Adam Bremensis, Gesta Hammaburgensis Ecclesiae pontificum, ed. Johann Martin Lappenberg, Monumenta Germaniae Historica, IV, 27 (Hannoverae 1846); Franco Cardini, Alle radici della cavalleria medievale (Città di Castello: La Nuova Italia, 1981), 559-563.
} 
In northern European myths, the horse is undoubtedly a liminal creature ${ }^{50}$ : it is often credited with the ability to pass from the Realm of the Living to the Realm of the Dead acting as means of transportation for the journey to the Underworld - being frequently associated with Death and the Spirit world, the horse acts as a transcendent medium, and it is also commonly endowed with the ability to foretell fates and predict death. ${ }^{51}$ Though the connection between the Transcendent/Deity and beasts/monsters (monstrum $=$ at first: "divine omen", then: "supernatural thing/being") is not unique to the Germanic and CentralAsian cultures, ${ }^{52}$ it is particularly strong in the Steppe cultures, where animals frequently represent a point of convergence between the earthly and the unearthly. ${ }^{53}$ They are often perceived as beasts: the incarnation of a supernatural alteritas; a concept typical of shamanic beliefs and warriors connoted by a totemic lore, ${ }^{54}$ like the Lombards' Cynocephali described by Paul the Deacon: "id est canini capitis homines." 55

In the steppe cultures, shamanic rituals, zoomorphic symbols, afterlife, and religion were indeed deeply entangled. ${ }^{56}$ Such "sensitivity" in relation to animal imagery was probably incorporated and further developed by the Lombards through their contact with the Avars, that reached the Pannonian Basin from the Eurasian Steppes, like them, around the mid-six ${ }^{\text {th }}$ century AD. It is, after all, a known fact that during the four-century migration that led the

50 Odin's eight-legged horse Sleipnir is a recurring shamanic theme, common among the Siberian and Indo-Iranian cultures; moreover, the mythical tree Yggdrasil (central to the shamanic lore), means: "horse of Ygg (Odin)"; Georges Dumézil, Gli Dei dei Germani (Milano: Adelphi, 1988); Mircea Eliade, Lo sciamanismo e le tecniche dell'estasi (Roma: Mediterranee, 1985), 406.

51 Tacitus writes about the custom, among the German people of his time, to keep in high regard certain "sacred" horses, whose neigh could foretell fate; Tacitus, Germania, 10.

52 Johannes Scotus Eriugena gives an effective definition of the relationship between animals and the Transcendent: the best way to celebrate God is by negation and by "mantling him with the image of a beast": "Plus eum significat [...] qui figuram bestialem ipsi circumdat," something that the medieval Latin religious iconography embodies very well; Iohannes Scotus Eriugena, Expositiones super Hierarchiam coelestem Sancti Dionysii, ed. Jeanne Barbet, CCSL, (Turnhout: Brepols, 1975), 52-53; Francesco Zambon, L'alfabeto simbolico degli animali, (Milano-Trento: Carocci, 2001), 45; Giovanni Zuanazzi, Pensare l'assente Alle origini della teologia negativa (Roma: Città Nuova, 2005).

53 An overview on men and animals in the Early Middle Ages: L'uomo di fronte al mondo animale nell'Alto Medioevo - Atti della XXXI Settimana di Studio del CIS AM (Spoleto: Fondazione CISAM, 1985).

${ }^{54}$ Like berserkir ("who has the skin of a bear"), and ùlfhedhnar ("who has the skin of a wolf"), legendary Viking warriors that, during propitiatory ceremonies, wore zoomorphic masks of their totem animal, as vehicles to achieve a sacred rapture state. Stefano Gasparri, La cultura tradizionale dei Longobardi - struttura tribale e resistenze pagane (Spoleto: Fondazione CISAM, 1983), 17; Karl Hauck, "Lebensnormen und Kultmythen in germanischen Stammes - und Herrschergenealogien," Saeculum 6 (1955): 186-223; Michael P. Speidel, Ancient Germanic Warriors Warrior Styles from Trajan's Column to Icelandic Sagas (London: Routledge, 2004).

55 The history of the Lombards is a path marked by various circumstances of inter-ethnic confrontation. If the most famous is the one in which Odin/Wotan - giving the Lombards their new name and the victory against the Vandals - sanctions the start of their new identity (Origo Gentis Langobardorum), equally interesting is the one about the Cynocephali. Being outnumbered by the Assipitti, the Lombards elaborate a cunning stratagem: they make them believe to have among their ranks some dog-headed blood-thirsty warriors. Their enemies, scared, agree to a single combat duel and lose; Paolus Diaconus, Historia Langobardorum, I, 11, 27.

56 And remained so for a while. Ibn Faḍlān, ambassador of the Abbasid caliph, sent to the king of the Volga Bulgars in the early tenth century, witnessed a complex funerary ritual in which a Khazar man was buried with rich grave goods and a sacrificial horse, as a means of travel to the Afterlife; M. Canard, "La relation du voyage d'Ibn Fadlan chez les Bulgares de la Volga", in Annales de l'Institut d'etudes Orientales, XVT (Paris, 1958), 75-76. 
Lombards from the lower Elbe, through the Danube and Pannonia, and finally to Italy, they undoubtfully underwent a process of deep transformation and ethnical merging, becoming a people probably quite different from the one that started the journey, on multiple levels. ${ }^{57}$ The interaction between Lombards and Avars is well documented in the written sources, ${ }^{58}$ and the archaeological data too seem to confirm a shared funerary culture on many aspects (closer to the Italian Lombard one especially in the early stages of the Avars' Pannonian phase) ${ }^{59}$ The custom of horse burials is recorded for the Early Avar Period (late sixth to late seventh century), and appears even more widespread in the Late Avar Period (eighth century). Even though Avar equine burials in Pannonia are mainly associated with adult males (either in the same pit or in close connection), it is important to note that cases of female and subadult individuals are not unusual. ${ }^{60}$ To what extent the exchanges between nomadic people happened in the Age of Migration has been confirmed by population genetics studies as well, especially regarding Lombards and Avars. ${ }^{61}$ Broader bioarchaeometric analysis performed on burial grounds in the areas touched by the Lombard migration seem to indicate a long story of complex dynamics and ethnic admixture, ${ }^{62}$ hence confirming a significant cultural mobility that influenced the ritual codes and forms of expression of many gentes in the Age of Migration.

As in the North-Western European "Germanic" world and in the nomadic Central-Asian one, the burial of a horse with an individual in the Italian Lombard funerary culture suggests, on a symbolic level, that the animal was supposed to follow - or to carry - the deceased to the Afterlife. However, while investigating the Lombard funerary culture it is essential to keep in mind that these polygenic customs of pre-migratory influence that appear pagan were, by the late sixth century, integrated without any apparent contradiction in what was, at least in theory, the funerary practice of an Arian Christian group. ${ }^{63}$ Traditions like the animal sacrifice were probably no longer conscious beliefs, but they were still deep-rooted rituals sublimated in a transitional Christianity and, as such, culturally essential. The act of burying elements of great wealth with an individual was therefore by that time, a public performance of status in front of the gathered community. In other words, a way to reaffirm social roles and

${ }^{57}$ W. Pohl, "Conceptions of Ethnicity in Early Medieval Studies," in Debating the Middle Ages: Issues and Readings, ed. L.K. Little and B.H. Rosenwein (Oxford: Blackwell Publishing, 1998), 17-28.

58 Paulus Diaconus, Historia Langobardorum, I, 27, 64-69.

59 T. Vida, "La ricerca e le ultime scoperte longobarde in Pannonia: una sintesi," in Necropoli Longobarde in Italia: indirizæi della ricerca e nuovi dati, ed. Elisa Possenti (Trento: Museo Castello Buonconsiglio, 2014), 59.

${ }^{60}$ I. Bede, "The Status of Horses in Late-Avar Period Society in the Carpathian Basin," in The very beginning of Europe? Cultural and Social Dimensions of Early-Medieval Migration and Colonisation (5th-8th centuries), ed. Rica Annaert, Tinne Jacobs, Ingrid In't Ven \& Steffi Coppens (Brussels: Flanders Heritage Agency, 2012), 42-43.

${ }^{61}$ A. Gasparini, The Horse Lords of Campochiaro - Using funerary evidence to discover ethnic belonging and identity in VII century Southern Italy, dissertation, Supervisor: Prof. Dr. M.J. Versluys - Universiteit Leiden, Den Haag 2017, 59-73.

${ }^{62}$ Samples from 9 necropolises between Czech Republic, Hungary, and Italy, both from pre-Lombards and post-Lombards passage; S. Vai - A. Brunelli - A. Modi et al., "A genetic perspective on LongobardEra migrations," European Journal of Human Genetics, 27, (2019), 647-656.

${ }^{63}$ According to the sources, when the Lombards left Pannonia to enter Italy in AD 568, they were, at least at an institutional level, Christians of Arian faith. Moreover, Procopius describes them as Christians already at the end of the fifth century, in eloquent juxtaposition to the pagan Herules; Procopius, Bella, VI, 14, 9, ed. Domenico Comparetti (Milano: Garzanti, 2015); P. Cesaretti, "I Longobardi di Procopio," in I Longobardi e la storia - un percorso attraverso le fonti, ed. Francesco Lo Monaco, Francesco Mores (Roma: Viella, 2012), 19-73. 
connection and to secure the family's stability. ${ }^{64}$ From this perspective, horses were a powerful symbol and chiefly, an elite one, reserved to a few unique individuals with a nonreplicable prominence in their group.

\section{Why the horse? Why the rider?}

In Italy the 14 Lombard necropolises properly characterized by the presence of horses, date to the seventies of the sixth and the first half of the seventh centuries. ${ }^{65}$ In the search for recurring patterns, the following elements emerged. The animal burials, when dateable, have been all ascribed to the cemetery's first phase of usage. ${ }^{66}$ Another common aspect is that, when verifiable, the horse's sex was always male. Also, it is important to note that that, except for Campochiaro, ${ }^{67}$ this custom was always something reserved to the few - like in Spilamberto - and mostly to only one individual for each necropolis. ${ }^{68}$

We need to ask one fundamental question: did a horse burial, for a Lombard community of the late sixth / early seventh century, automatically mean an involvement in military practice and, therefore, a connection to a role of political leadership? Based on the current research, it appears that the people buried with a horse were not always individuals who could be automatically interpreted as warriors: the cultural background of this custom seems highly complex. According to the anthropological and paleopathological studies performed on the remains, cases like the ladies of Spilamberto or the young boy of Villa Lancia (where the boy was buried with the scramasax but not with the spatha, ${ }^{69}$ and he did not have the distinctive

${ }^{64}$ Irene Barbiera, Changing Lands in Changing Memories. Migration and Identity during the Lombard Invasion (Firenze: All'Insegna del Giglio, 2005); Irene Barbiera, Memorie sepolte. Tombe e identità nell'alto Medioevo, secoli V-VIII (Roma: Carocci, 2012); C. Giostra, "Luoghi e segni della morte in età longobarda: tradizione e transizione nelle pratiche dell'aristocrazia," in Archeologia e Società tra Tardo-antico e Alto Medioevo, ed. Gian Pietro Brogiolo - Alexandra Chavarrìa Arnau, (Mantova: Società Archeologica Mantova, 2007), 311-344; C. La Rocca, "Donare, distribuire e spezzare. Pratiche di conservazione della memoria e dello status in Italia tra VIII e IX secolo," in Sepolture tra IV e VIII secolo, ed. Gian Pietro Brogiolo and Gisella Cantino Wataghin (Mantova: Società Archeologica Padana, 1998), 77-87; C. La Rocca, "L'archeologia e i longobardi in Italia. Orientamenti, metodi, linee di ricerca," in Il regno dei Longobardi in Italia - archeologia, società e istituzioni, ed. Stefano Gasparri (Spoleto: Fondazione CISAM, 2004), 173-233; C. La Rocca, "Tombe con corredi, eticità e prestigio sociale: l'Italia longobarda del VII secolo attraverso l'interpretazione archeologica," in Archeologia e storia dei Longobardi in Trentino (secoli VI-VIII), ed. S. Gasparri (Mezzolombardo, 2008), 55-75.

65 The custom of horse burial among the people of the same civilization that remained beyond the Alps, is attested between the mid-fifth to the eighth century; I. Ahumada Silva, "Le tombe e i corredi," in La collina di San Mauro a Cividale del Friuli. Dalla necropoli longobarda alla chiesetta bassomedievale, ed. Isabel Ahumada Silva (Firenze: All'Insegna del Giglio, 2010), 104; J. Oexle, "Merowingerzeitliche Pferdebestattungen - Opfer oder Beigaben?” Frubmittelalterliche Studien 18 (1984): 139.

66 With a longer time of use for Campochiaro, see footnote n. 11.

${ }^{67}$ In the two necropolises of Campochiaro, 19 equine burials have been discovered; however, this large number, when compared to the total number of the graves in the area, it results in being about less than $10 \%$.

68 A similar statistic rate has been suggested for the Avar Period in Pannonia: among about 60.000 burials, around 6.000 are estimated to be horse burials (10\% ca.). T. Vida, "The early and middle Avar period (568-turn of the 7th-8th centuries)," in Hungarian archaeology at the turn of the millennium, ed. Zs. Visy - M. Nagy (Budapest, 2003), 302-307.

${ }^{69}$ The scramasax is a type of small dagger, widespread among the Germanic peoples of the Age of Migration. In the Lombard culture carrying a scramasax and/or a spatha, meant to be a free individual. 
osteological markers of the warrior),$^{70}$ all suggest that there was not a necessarily link with military training and a constant practice of armed combat. On the other hand, the people interred in different investigated sites, for example Campochiaro and Collegno, ${ }^{71}$ showed clear signs of violent death. Although, as it has already been underlined, violent death does not necessarily mean death in battle and if it was stated that they were warriors involved in warfare, then it has to be investigated first where and against whom they fought. ${ }^{72}$ Besides, weapons and equestrian elements should be interpreted primarily in line with the Lombard culture: that is, as markers of a free individual. Thus, the men buried with weapons were probably not all warriors and, therefore, the ones buried with a horse cannot be automatically identified as knights or military leaders, ${ }^{73}$ especially because, as already stressed, graves do not necessarily reflect the living social roles of the deceased, i.e. the "space" of death is a ritual one and does not tell an organic story of everyday life. Horses, weapons, and other equestrian symbols among grave-goods were probably elements of a symbolic language largely dependent (due to cultural reasons) on the warfare sphere, from which the symbols of social preeminence were borrowed, but without implying a factual involvement in warfare. From this perspective, the fact that horses were buried in connection to the three young women in Spilamberto appears less exceptional than one may think.

It is difficult to determine to what extent a horse burial meant wealth in life. Currently, we do not know the logic behind the Lombard grave-goods and their distribution. ${ }^{74}$ To assert that the individuals interred with a horse were certainly the richest among their people would be hasty. While, for instance, the burials of the ladies of Spilamberto and the young boy of the necropolis of Villa Lancia appeared quite lavish and above the average (but not the richest of the necropolis, nor the only ones rich enough to sacrifice a horse), the same cannot be said of the horse burials from the other 12 sites investigated. In fact, in the necropolises of Nocera Umbra, Campochiaro and San Mauro, the tombs with a horse burial had fine grave goods but were overall below the average compared to the other burials of the same generation.

\footnotetext{
${ }^{70}$ In the cemetery of Villa Lancia, a young man of about 25 years old was buried next to a horse; E. Bedini and E. Petiti, "Sepolture animali in necropoli longobarde: gli esempi del Piemonte," in Necropoli Longobarde in Italia: indirizzi della ricerca e nuovi dati, ed. Elisa Possenti (Trento: Museo Castello Buonconsiglio, 2014), 550-556; G. Pantò, C. Giostra, F. Barello, E. Bedini, E. Petiti, "Un nucleo di sepolture longobarde a Villa Lancia di Testona", in Quaderni della Soprintendenza Archeologica del Piemonte 28 (2013), 89-118; G. Pantò, F. Occelli, "Moncalieri, frazione Testona, parco di Villa Lancia. Abitato e necropoli di età longobarda," Quaderni della Soprintendenza Archeologica del Piemonte 24 (2009), 227-231.

${ }^{71}$ E. Bedini and F. Bertoldi, "Aspetto fisico, stile di vita e stato di salute del gruppo umano," in Presenze longobarde. Collegno nell'alto medioevo, ed. Luisella Pejrani Baricco (Torino: Soprintendenza per i beni archeologici del Piemonte, 2004), 217-236; E. Bedini and E. Petiti, "Longobardi in Piemonte: gli aspetti paleobiologici," in Necropoli Longobarde in Italia: indirizzi della ricerca e nuovi dati, ed. Elisa Possenti (Trento: Museo Castello Buonconsiglio, 2014), 532-541; M. G. Belcastro and F. Facchini, "La popolazione altomedievale di Vicenne-Campochiaro: studio antropologico," in I beni culturali nel Molise. Il Medioevo, ed. G. De Benedettis (Campobasso, 2004), 133-150.

72 Aldo A. Settia, "Una fara in Collegno," Bollettino storico-bibliografico subalpino CIII (2005): 273.

${ }^{73}$ L. Paroli, "Mondo Funerario," in I Longobardi. Dalla caduta dell'Impero all'alba dell'Italia, ed. Gian Pietro Brogiolo and Alexandra Chavarrìa Arnau (Milano: Silvana, 2007), 206.

${ }^{74}$ Studies based on gender, age and wealth tried to define the rules through which grave-good were placed with the deceased, but the scenario seems quite hard to understand. Some studies identify a bigger investment in those ages relevant for the community; a logic similar to the one behind the Wergild; G. Halsall, "Burial, ritual and Merovingian society," in The Community, the Family and the Saint: Patterns of Power in Early Medieval Europe, ed. Joyce M. Hill and Mary Swan (Turnhout: Brepols Publishers, 1998), 325-338; W. Pohl, “L’universo barbarico," in Storia medievale (Roma: Donzelli, 1998), 80.
} 
If, therefore, the people buried with a horse were neither (or at least not always) the politico-military leaders of their community, endowed with preeminent richness, nor were the only ones able to afford and sacrifice a horse, who were these "extraordinary" individuals? They must have been people whose social relevance was not only well known and undoubtable, but also hard to emulate, at least for those who witnessed the ritual without imitating it. As for the following generations, we can assume that the settlement and the socioeconomic dialogue of the Lombards with the new territories and the local culture caused that change of mind-set that gradually led to the transformation of their traditions. ${ }^{75}$

One plausible theory is probably the more obvious one: this ritual implied the very high social status of the individual, in terms of a wider meaning of preeminence, authority and social relevance in the community. These individuals may not necessarily have always been connected to a role of political leadership, but their importance was doubtlessly shared, undeniable, and broadly acknowledged.

\section{Conclusions}

A social role, even if relevant, is not always expressed through archaeologically tangible material signs. ${ }^{76}$ The horse burials discovered in Italy, just as other evocative rites or grave goods, might have association beyond political power or beyond the leading of an army: the three young ladies of Spilamberto apparently confirm this theory. Such auctoritas was expressed through symbols taken from the domain of warfare and is probably linked more to a sublimated mythical inheritance that resurfaced in burial rituals than to actual military practice in life. After all, the realm of the horse in the Nordic and Central-Asian cultures, which deeply influenced the Lombards during their migration, is incredibly vast. It ranges from a connection with warfare and hunting to a shamanic and totemic dimension, passing through being a symbol of fertility, until finally reaching what seems to be an inevitable tie with death. The horses buried in the Italian Lombard necropolises are hence, perhaps, an expression of the survival of an old way of thinking. In that context, the animals, and the horse especially, were probably elements of an allegorical language made of inherited images and through which this culture kept expressing itself for a long time.

\section{References}

Bremensis, Adam. Gesta Hammaburgensis Ecclesiae pontificum, ed. Johann Martin Lappenberg, Monumenta Germaniae Historica, IV, 27. Hannoverae, 1846.

Ahumada Silva, Isabel, ed. La collina di San Mauro a Cividale del Friuli. Dalla necropoli longobarda alla chiesetta bassomedievale. Firenze: All'Insegna del Giglio, 2010.

. "La necropoli di San Mauro in rapporto alle altre aree sepolcrali longobarde cividalesi."

In Necropoli Longobarde in Italia: indirizzi della ricerca e nuovi dati, ed. Elisa Possenti, 319-338. Trento: Museo Castello Buonconsiglio, 2014.

\footnotetext{
${ }^{75}$ C. La Rocca, "Donare, distribuire e spezzare."; V. La Salvia, "La diffusione della staffa nell'area merovingia orientale alla luce delle fonti archeologiche," in Temporis Signa. Archeologia della Tarda Antichità e del Medioevo (Spoleto: Fondazione CISAM, 2007), 155-171; V. La Salvia, "Cultura materiale e materialismo culturale. Ancora intorno al trasferimento di tecnologia, ai gruppi etnici e all'analisi dei contesti archeologici altomedievali", in Atti del V Congresso Nazionale di Archeologia Medievale, ed. Giuliano Volpe and Pasquale Favia (Firenze: All'Insegna del Giglio, 2009), 31-35.

${ }^{76}$ G. P. Brogiolo, "Archeologia e società tra Tardo Antico e Alto Medioevo," in Archeologia e società tra Tardo Antico e Alto Medioevo, ed. Gian Pietro Brogiolo and Alexandra Chavarrìa Arnau (Mantova: Società Archeologica Padana, 2007), 8.
} 
—. "Le tombe e i corredi." In La collina di San Mauro a Cividale del Friuli. Dalla necropoli longobarda alla chiesetta bassomedievale, ed. Isabel Ahumada Silva, 21-163. Firenze: All'Insegna del Giglio, 2010.

Alhaique, F. and E. Cerilli. "Analisi Osteologiche." In Nelle campagne della Rosa. Dieci anni di ricerche archeologiche a Rosà, ed. Elena Pettenò 124-126. Bassano: Editrice Artistica Bassano, 2004.

Azzara, Claudio and Gasparri, Stefano, ed. Le leggi dei longobardi - storia, memoria e diritto di un popolo germanico. Milano: Viella, 2005.

Azzara, Claudio and Sergi, Giuseppe. Invasione o migrazione? I longobardi in Italia. Turin: Aragno, 2006.

Barbiera, Irene. Changing Lands in Changing Memories. Migration and Identity during the Lombard Invasion. Firenze: All'Insegna del Giglio, 2005.

_ _ "Le dame barbare e i loro invisibili mariti: le trasformazioni dell'identità di genere nel V secolo." In Le trasformazioni del V secolo: l'Italia, i barbari e l'Occidente romano, Atti del seminario di Poggibonsi (18 - 20 ottobre 2007), ed. Paolo Delogu and Stefano Gasparri, 123-155. Turnhout: Brepols, 2010.

- Memorie sepolte. Tombe e identità nell'alto Medioevo (secoli V-VIII). Rome: Carocci, 2012.

—. "Il mistero delle donne scomparse. Sex-ratio e società nel medioevo italiano." In Archeologia Medievale XXXV (2008): 491-501.

Bede, I. "The Status of Horses in Late-Avar Period Society in the Carpathian Basin." In The very beginning of Europe? Cultural and Social Dimensions of Early-Medieval Migration and Colonisation (5th-8th centuries), ed. Rica Annaert, Tinne Jacobs, Ingrid In't Ven \& Steffi Coppens, 41-50. Brussels: Flanders Heritage Agency, 2012.

Bedini, E. "Il cavallo." In Presenze longobarde. Collegno nell'alto medioevo, ed. Luisella Pejrani Baricco, 137-240.

Bedini, E. and F. Bertoldi. "Aspetto fisico, stile di vita e stato di salute del gruppo umano." In Presenze longobarde. Collegno nell'alto medioevo, ed. Luisella Pejrani Baricco, 217-236. Turin: Soprintendenza per i beni archeologici del Piemonte, 2004.

Bedini, E., and E. Petiti. "Fedeli oltre la morte. Sepolture di animali in necropoli longobarde. Gli esempi del Piemonte." In Atti del VI Convegno Nazionale di Archeozoologia, ed. Jacopo De Grossi Mazzorin, Daniela Saccà and Carlo Tozzi, 335-338. Lucca: Ass. Italiana Archeozoologia, 2012.

Bedini, E., and E. Petiti. "Longobardi in Piemonte: gli aspetti paleobiologici." In Necropoli Longobarde in Italia: indirizzi della ricerca e nuovi dati, ed. Elisa Possenti, 532-541. Trento: Museo Castello Buonconsiglio, 2014.

—. "Sepolture animali in necropoli longobarde: gli esempi del Piemonte." In Necropoli Longobarde in Italia: indirizzi della ricerca e nuovi dati ed. Elisa Possenti, 550-556. Trento: Museo Castello Buonconsiglio, 2014.

Belcastro, G., and F. Facchini. "La popolazione altomedievale di Vicenne-Campochiaro: studio antropologico." In I beni culturali nel Molise. Il Medioevo, ed. G. De Benedettis, 133150. Campobasso, 2004.

Bleichsteiner, R. "Roßweihe und Pferderennen im Totenkult der kaukasischen Völker." Wiener Beiträge zur Kulturgeschicbte und Linguistik IV (1936): 413-495.

Breda, Andrea, ed. Il Tesoro di Spilamberto - Signori Longobardi alla frontiera. Spilamberto: Comune di Spilamberto, 2010.

Brogiolo, G. P. “Archeologia e società tra Tardo Antico e Alto Medioevo.” In Archeologia e società tra Tardo Antico e Alto Medioevo, ed. Gian Pietro Brogiolo and Alexandra Chavarrìa Arnau, 7-20. Mantova: Società Archeologica Padana, 2007. 
Brather, S. "Vestito, tomba ed identità fra Tardo Antico ed Alto Medioevo." In Archeologia e società tra Tardo Antico e Alto Medioevo, ed. Gian Pietro Brogiolo and Alexandra Chavarrìa Arnau, 299-310. Mantova: Società Archeologica Mantova, 2007.

Canard, M. "La relation du voyage d'Ibn Fadlan chez les Bulgares de la Volga."In Annales de l'Institut d'etudes Orientales, XVI, 41-145. Paris, 1958.

Cardini, Franco. Alle radici della cavalleria medievale. Città di Castello, 1981.

Cesaretti, P. "I Longobardi di Procopio." In I Longobardi e la storia - un percorso attraverso le fonti, ed. Francesco Lo Monaco and Francesco Mores, 19-73. Rome: Viella, 2012.

Chavarrìa Arnau, A., and T Lewit. "Uomini e animali nell'Italia longobarda." In Longobardi un popolo che cambia la storia, ed. Gian Pietro Brogiolo, Federico Marazzi, Caterina Giostra, 162-165. Milan: Skira, 2017.

Ceglia, V. "La necropoli di Campochiaro (Italia)." In Roma e i Barbari. La nascita di un nuovo mondo, ed. Jean-Jacques Aillagon, 469-475. Milan: Skira, 2008.

Ceglia, V. and I. Marchetta. "Nuovi dati dalla necropoli di Vicenne a Campochiaro." In La trasformazione del mondo romando e le grandi migrazioni. Nuovi popoli dall'Europa Settentrionale e Centro-orientale alle coste del Mediterraneo, ed. Carlo Ebanista - Marcello Rotili, 217-238. Cimitile: Tavolario Edizioni, 2012.

Chiesa Isnardi, Gianna. I miti nordici. Milan: Longanesi, 1991.

Cross, P. J. "Horse Burial in First Millennium AD Britain: Issues of Interpretation." European Journal of Archaeology 14 (2011): 190-209.

De Vingo, P. "Corredo funerario ed elementi del costume femminile della tomba 62 della necropoli longobarda di Spilamberto (MO), Cava di Ponte del Rio." In Medioevo Svelato Storie dell'Emilia-Romagna attraverso l'archeologia, ed. Sauro Gelichi,- Cinzia Cavallari and Massimo Medica, 230-234. Bologna: Ante Quem, 2018.

—. "Riding to Walhalla: The Role of Horses and Horsemen in Italian Funerary Rituals in the Early Middle Age." In Tra i Longobardi del Sud: Arechi II e il Ducato di Benevento, ed. Marcello Rotili, 537-566. Padova: Il Poligrafo, 2017.

—. "Spilamberto, Archeologia di una necropoli longobarda." In Il Tesoro di Spilamberto Signori Longobardi alla frontiera, ed. Andrea Breda, 29-67. Spilamberto: Comune di Spilamberto, 2010.

De Vingo, P., P. Baronio, and G. Maddaleno. "Spilamberto (MO), Necropoli Longobarda." In Medioevo Svelato - Storie dell'Emilia-Romagna attraverso l'archeologia, ed. Sauro Gelichi, Cinzia Cavallari and Massimo Medica, 203-207. Bologna: Ante Quem, 2018.

Paulus diaconus. Historia Langobardorum, ed. Lidia Capo. Milan, 1992.

Dumézil, Georges. Gli Dei dei Germani. Milan: Adelphi, 1988.

Eliade, M. Lo sciamanismo e le tecniche dell'estasi. Rome: Mediterranee, 1985.

Farello, P. "I cavalli longobardi di Spilamberto." In Il Tesoro di Spilamberto - Signori Longobardi alla frontiera, ed. Andrea Breda, 91-97. Spilamberto: Comune di Spilamberto, 2010.

Fedele, A. "La deposizione del cavallo nei cimiteri longobardi: dati e prime osservazioni." In Archeologia dei Longobardi. Dati e metodi per nuovi percorsi di analisi, ed. Caterina Giostra, 59-82. Mantova, 2017.

- "Horse burials among the Lombards and Avars. Some differences and similarities between the Germanic and Nomadic rituals." In The Materiality of the Horse, ed Miriam A. Bibby - Brian G. Scott, 239-260. Budapest: Trivent, 2020.

Fedele, A., I. Marchetta, and D. Colombo. "Ritualità e rappresentazione funeraria nelle tombe di Vicenne (Campochiaro, CB). Una sintesi." In Prima e dopo Alboino: sulle tracce dei Longobardi, ed. Carlo Ebanista - Marcello Rotili, 295-314. Naples: Tavolario Edizioni, 2019. 
Fiorin, E. "Alcune valutazioni preliminari sui defunti longobardi di Spilamberto." In Il Tesoro di Spilamberto - Signori Longobardi alla frontiera, ed. Andrea Breda, 87-89. Spilamberto: Comune di Spilamberto, 2010.

Fortunati Zuccalà, M., S. Di Martino, and M. Di Giancamillo. "Bagnatica (BG), Via SS. Redentore. Sepoltura rituale di un cavallo." Notiziario della Soprintendenza Archeologica della Lombardia (1995-97): 48-50.

Gasparri, Stefano. La cultura tradizionale dei Longobardi - struttura tribale e resistenze pagane. Spoleto: Fondazione CISAM, 1983.

Gasparri, Stefano. "I Germani immaginari e la realtà del regno. Cinquant'anni di studi sui Longobardi." In I Longobardi dei ducati di Spoleto e Benevento. Atti del XVI congresso internazionale di studi sull'alto medioevo I, 3-28. Spoleto: Fondazione CISAM, 2003.

—. "La memoria storica dei Longobardi." In Le leggi dei longobardi - storia, memoria e diritto di un popolo germanico, ed. Claudio Azzara - Stefano Gasparri, xvii-xxxvii. Milan: Viella, 2005.

_. "La migrazione longobarda in Italia tra mito e realtà." In Le migrazioni nell'alto medioevo, Atti della LXVI Settimana di Studio del CISAM, vol. 1, 375-393. Spoleto: Fondazione CISAM, 2019.

— - ed. Il Regno dei Longobardi in Italia - Archeologia, società e istituzioni, Spoleto: Fondazione CISAM, 2004.

Gasparri, Stefano and C. La Rocca, ed. Carte di famiglia. Strategie, rappresentazione e memoria del gruppo familiare di Totone di Campione (721-877). Rome: Viella, 2005.

Gasparini, Anthony. The Horse Lords of Campochiaro - Using funerary evidence to discover ethnic belonging and identity in VII century Southern Italy, dissertation, Supervisor: Prof. Dr. M. J. Versluys, Universiteit Leiden, Den Haag 2017.

- (Re)Viewing the Evidence: Using traditional and modern techniques to question gender and migration in the 7 th century necropoleis of Campochiaro (Molise, Italy), unpublished dissertation, Supervisor: Prof. M. G. Belcastro. University of Bologna, Bologna 2019.

Gelichi, S. and C. La Rocca, ed. Tesori: forme di accumulazione della ricchezza nell' alto Medioevo, secoli $V$-XI. Rome: Viella, 2004.

Genito, B. "Sepolture con cavallo da Vicenne (CB): un rituale nomadico di origine centroasiatica." In Atti del I Congresso Nazionale di Archeologia Medievale, ed. Sauro Gelichi, 1-4. Firenze: all'Insegna del Giglio, 2001.

Giordani, N. "Il pendente-fibula della tomba femminile 62." In Il Tesoro di Spilamberto - Signori Longobardi alla frontiera, ed. Andrea Breda, 77-85. Spilamberto: Comune di Spilamberto, 2010.

Giostra, C. "Luoghi e segni della morte in età longobarda: tradizione e transizione nelle pratiche dell'aristocrazia." In Archeologia e Società tra Tardo-antico e Alto Medioevo, ed. Gian Pietro Brogiolo - Alexandra Chavarrìa Arnau, 311-344. Mantova: Società Archeologica Mantova, 2007.

—_. "Verso l'aldilà: i riti funerari e la cultura materiale." In Longobardi - un popolo che cambia la storia, ed. Gian Pietro Brogiolo, Federico Marazzi, Caterina Giostra, 60-67. Milano: Skira, 2017.

Iohannes Scotus Eriugena, Expositiones super Hierarchiam coelestem Sancti Dionysii, ed. JEANNE BARBET, CCSL. Turnhout: Brepols 1975.

Halsall, G. "Burial, ritual and Merovingian society." In The Community, the Family and the Saint: Patterns of Power in Early Medieval Europe, ed. Joyce M. Hill - Mary Swan, 325-338. Turnhout: Brepols, 1998.

—. Settlement and social organization. Cambridge: Cambridge University Press, 1995.

Hauck, K. "Lebensnormen und Kultmythen in germanischen Stammes - und Herrschergenealogien." Saeculum 6 (1955): 186-223.

Jones, P., and N. Pennick. A History of Pagan Europe. London: Routledge, 1995. 
Labate, D. "L'insediamento antico nell'area della necropoli longobarda di Spilamberto." In Il Tesoro di Spilamberto - Signori Longobardi alla frontiera, ed. Andrea Breda, 21-27. Spilamberto: Comune di Spilamberto, 2010.

La Rocca, C. "L'archeologia e i longobardi in Italia. Orientamenti, metodi, linee di ricerca." In Il regno dei Longobardi in Italia - archeologia, società e istituzioni, ed. Stefano Gasparri, 173233. Spoleto: Fondazione CISAM, 2004.

—. "Donare, distribuire e spezzare. Pratiche di conservazione della memoria e dello status in Italia tra VIII e IX secolo." In Sepolture tra IV e VIII secolo, ed. Gian Pietro Brogiolo and Gisella Cantino Wataghin, 77-87. Mantova: Società Archeologica Padana, 1998.

_. "Foreign dangers: activities, responsibilities and the problem of women abroad." Early medieval Europe 23 (2015): 410-435.

__ . "Reperti longobardi della necropoli di Povegliano, conservati nel Museo di Castelvecchio di Verona." In I Longobardi e la guerra: da Alboino alla battaglia sulla Livenza - sec. VI-VIII, 144-158. Roma: Viella, 2004.

—. "Storia di genere e archeologia dell'alto medioevo: note sul dibattito europeo." In Archeologia e società tra Tardo Antico e Alto Medioevo, ed. Gian Pietro Brogiolo and Alexandria Chavarría Arnau, 265 - 277. Mantova: SAP, 2007.

—. "Tombe con corredi, eticità e prestigio sociale: l'Italia longobarda del VII secolo attraverso l'interpretazione archeologica." In Archeologia e storia dei Longobardi in Trentino (secoli VI-VIII), ed. S. Gasparri, 55-75. Mezzolombardo, 2008.

La Salvia, V. "Cultura materiale e materialismo culturale. Ancora intorno al trasferimento di tecnologia, ai gruppi etnici e all'analisi dei contesti archeologici altomedievali." In Atti del $V$ Congresso Nazionale di Archeologia Medievale, ed. Giuliano Volpe - Pasquale Favia, 31-35. Firenze: All'Insegna del Giglio, 2009.

-. "La diffusione della staffa nell'area merovingia orientale alla luce delle fonti archeologiche." In Temporis Signa. Archeologia della Tarda Antichità e del Medioevo, 155-171. Spoleto: Fondazione CISAM, 2007.

Lo Monaco, Francesco - Mores, Francesco, ed. I Longobardi e la storia - un percorso attraverso le fonti. Rome: Viella, 2012.

L'uomo di fronte al mondo animale nell'Alto Medioevo - Atti della XXXI Settimana di Studio del CIS AM. Spoleto: Fondazione CISAM, 1985.

Marinato, M. and A. Chavarria Arnau. "Approcci multidisciplinari per lo studio dei contesti cimiteriali longobardi: il sito di Spilamberto Cava Ponte del Rio (MO).” In VIII Congresso nazionale di Archeologia Medievale, 33-37. Firenze: All'Insegna del Giglio, 2018.

Menotti, E. M., P. M. De Marchi, and- L. Miazzo. "La necropoli longobarda a Sacca di Goito." In La necropoli longobarda a Sacca di Goito. I primi materiali restaurati. Catalogo della mostra, ed. Elena M. Menotti, Paola M. De Marchi, Lucia Miazzo, 33-40. Mantova: PubliPaolini, 1994.

Merrifield, Ralph. Archaeology of Ritual and Magic. London: B.T. Batsford, 1987.

Origo Gentis Langobardorum, in Le leggi dei longobardi - storia, memoria e diritto di un popolo germanico, ed. Claudio Azzara and Stefano Gasparri. Milan: Viella, 2005.

Oexle, J. "Merowingerzeitliche Pferdebestattungen - Opfer oder Beigaben?" In Frubmittelalterliche Studien 18 (1984): 122-172.

Pantò, G., C. Giostra, F. Barello, E. Bedini, and E. Petiti. "Un nucleo di sepolture longobarde a Villa Lancia di Testona." Quaderni della Soprintendenza Archeologica del Piemonte 28 (2013): 89-118.

Pantò, G. And F. Occelli. "Moncalieri, frazione Testona, parco di Villa Lancia. Abitato e necropoli di età longobarda." Quaderni della Soprintendeña Archeologica del Piemonte 24 (2009): 227-231. 
Paroli, L. "Mondo Funerario." In I Longobardi. Dalla caduta dell'Impero all'alba dell'Italia, ed. Gian Pietro Brogiolo and Alexandra Chavarrìa Arnau, 203-209. Milan: Silvana, 2007.

Pasqui, A. And R. Paribeni. Necropoli barbarica di Nocera Umbra." Monumenti Antichi dei Lincei XXV (1918): 137-352.

Pohl, Walter. "Conceptions of Ethnicity in Early Medieval Studies." In Debating the Middle Ages: Issues and Readings, ed. L.K. Little and B.H. Rosenwein, 17-28. Oxford: Blackwell Publishing, 1998.

- Le origini etniche dell'Europa - Barbari e Romani tra antichità e medioevo. Rome: Viella, 2000.

Possenti, E. "Necropoli longobarde in Italia: lo stato della ricerca." In Necropoli Longobarde in Italia: indirizzi della ricerca e nuovi dati, ed. Elisa Possenti, 35-54. Trento: Museo Castello Buonconsiglio, 2014.

—. "Una tomba di cavaliere: della metà del V secolo da Arzignano (Vicenza)." Archeologia Medievale XXXVIII (2011): 431-475.

Price, N., C. Hedenstierna-Jonson et al. "Viking warrior women? Reassessing Birka chamber grave Bj.581.” Antiquity 93 (2019): 181-198.

Procopius. Bella, ed. Domenico Comparetti. Milano: Garzanti, 2015.

Provesi, C. I cavalieri e le loro donne. Uno studio dei corredi funerari di VI - VII secolo secondo una prospettiva di Gender, 1-14. Venice, 2011.

—. "Uomini e cavalli in Italia Meridionale: da Cassiodoro ad Alzecone." in Ipsam Nolam Barbari V astaverunt. L'Italia e il Mediterraneo Occidentale tra il V secolo e la metà del, ed. Carlo Ebanista and Marcello Rotili, 97-112. Cimitile: Tavolario Edizioni, 2010.

Reggiani, P. "Intervento di recupero e restauro delle ossa del cavallo della tomba 43." In La collina di San Mauro a Cividale del Friuli. Dalla necropoli longobarda alla chiesetta bassomedievale, ed. Isabel Ahumada Silva, 247-249. Firenze: All'Insegna del Giglio, 2010.

Reggiani, P. and J. Rizzi. "I resti del cavallo rinvenuti nella tomba di via Canove ad Arzignano (Vicenza)." In Atti del $3^{\circ}$ Convengo Nazionale di Archeozoologia, ed. Ivana Fiore, Giancarla Malerba, Salvatore Chilardi, 459-468. Roma: Istituto Poligrafico e Zecca dello stato, 2007.

Riedel, A., "Le inumazioni animali della necropoli longobarda di Povegliano (VR)." Annali dei Musei Civici di Rovereto 11 (1996): 53-98.

—. "Studio delle ossa del cavallo della tomba 43." In La collina di San Mauro a Cividale del Friuli. Dalla necropoli longobarda alla chiesetta bassomedievale, ed. Isabel Ahumada Silva, 241 246. Firenze: All'Insegna del Giglio, 2010.

Rupp, Cornelia. Das langobardische Gräberfeld von Nocera Umbra 1. Katalog und Tafeln. Firenze: All'insegna del Giglio, 2006.

Salvadori, F. "Indicatori archeozoologici nell'età della transizione." In Atti del V Congresso Narionale di Archeologia Medievale, ed. Giuliano Volpe - Pasquale Favia, 40-44. Firenze: All'Insegna del Giglio, 2009.

Settia, A. A. "Una fara in Collegno." Bollettino storico-bibliografico subalpino CIII (2005): 263-276.

Speidel, Michael P. Ancient Germanic Warriors Warrior Styles from Trajan's Column to Icelandic Sagas. London: Routledge, 2004.

Tacitus, Germania, ed. J. B. Rivers. Oxford: Oxford University Press, 2016.

Tuzzato, S. "L'insediamento di Brega." In Nelle campagne della Rosa. Dieci anni di ricerche archeologiche a Rosà, ed. Elena Pettenò, 82-98. Bassano: Editrice Artistica Bassano, 2004.

Vai, S., A. Brunelli A. Modi, et al.9 "A genetic perspective on Longobard-Era migrations." European Journal of Human Genetics 27 (2019): 647-656.

Vida, T. "The early and middle Avar period (568-turn of the 7th-8th centuries)." In Hungarian archaeology at the turn of the millennium, ed. Zs. Visy - M. Nagy, 302-307. Budapest, 2003.

—. "La ricerca e le ultime scoperte longobarde in Pannonia: una sintesi", in Necropoli Longobarde in Italia: indirizzi della ricerca e nuovi dati, ed. Elisa Possenti, 55-72. Trento: Museo Castello Buonconsiglio, 2014. 
Vita Barbati episcopi Beneventani, in Monumenta Germaniae Historica. Scriptores rerum Langobardicarum et Italicarum saec. VI-IX, ed. Georg Waitz, 555-563. Hannover, 1878.

Wickham, Chris. Framing the Early Middle Ages: Europe and the Mediterranean, 400-800. Oxford: Oxford University Press, 2005.

Zambon, Francesco. L'alfabeto simbolico degli animali. Milano-Trento: Carocci, 2001.

Zuanazzi, Giovanni. Pensare l'assente - Alle origini della teologia negativa. Rome: Città Nuova, 2005. 